\title{
FREMTIDEN PÅ MUSEET ${ }^{1}$
}

\section{PETER BJERREGAARD}

Kulturhistoriske museer har et anstrengt forhold til tiden. På mange måder er de legitimeret og drevet af historien. Ved at gemme på fortiden i materiel form kan museet kaste os ud i historiens vingesus, så vi kan se os selv i en større ramme end den hverdagslige. Men ofte bliver tilknytningen til historien så stærk, at museerne ender med at blive sært anakronistiske. Hvor de naturhistoriske museer kaster os ud i en svimlende uendelighed, og kunstmuseerne konstant udfordrer det bestående, står de kulturhistoriske museer tilbage med en smag af tiden, der minder mere om slidte fløjlsbuksebage og pibetobak end af stjernestøv og kaviar.

Der er i øjeblikket tendenser til, at etnografiske museer løsriver sig fra den kulturhistoriske ramme og lægger sig tættere op ad kunstmuseet (Sjørslev 2008; Schüssler; Faber 2003; Latour 2005), og enhver, der har haft en anelse interesse for repræsentationsdebatten, vil vide, at der er blevet eksperimenteret ikke bare med etnografisk skrivning, men også med udstillingsformer og -temaer samt relationer til publikum og repræsenterede på museerne igennem de seneste 30-40 år.

Men mens der eksperimenteres med svar på, hvordan det etnografiske museum kan udvikle sig, mangler vi måske stadig en grundigere overvejelse om, hvorfor det kulturhistoriske museum skal være andet end tilbageskuende.

I denne artikel vil jeg prøve at udvikle et argument for, at det kulturhistoriske museum ikke blot skal skabe troværdige repræsentationer af det allerede skete, men har et stort potentiale $i$ at se sig selv som et sted, hvor vi eksperimenterer med, hvad der kan komme til at ske - et sted, der er med til at forme fremtiden. På den måde kan det kulturhistoriske museum vende tilbage til sin oprindelige rolle som socialvidenskabens laboratorium.

Artiklen vil fokusere på etnografiske museer i ind- og udland, men den analytiske pointe kan udvides til også at gælde andre kulturhistoriske museer. 


\section{Udstillingens tider}

Lad os allerførst kigge på, hvordan tiden er indgået som en implicit faktor i etnografiske udstillinger. De tidligste egentlige etnografiske udstillinger var bygget på universalistiske ideer om menneskehedens udvikling. Indsamlinger fra hele verden blev samlet på museet, der fungerede som et laboratorium. Først på museet kunne man se den store sammenhæng mellem genstandene som dokumenter for den menneskelige kultur. ${ }^{2}$

\section{Fortid}

I den britiske sammenhæng brugte man genstandsmaterialet til at udbygge og understøtte kulturevolutionistiske ideer (Henare 2005; Shelton 2001). På museet kunne man rangordne genstandene i udviklingsserier fra det mest rudimentære til det mest udviklede. Det var for eksempel sådanne ideer, Pitt-Rivers ønskede at bygge sin senere så berømte samling over (Petch 2006). Ved at følge udviklingen af våben, værktøj m.v. kunne man mere generelt følge menneskehedens kulturelle udvikling. Den evolutionistiske udstilling understøttede således den evolutionistiske teori med en overbevisende æstetik. Ved at udstille serier af genstande i deres civilisatoriske udvikling tilbød museet et stærkt visuelt billede, der kunne være et lige så godt argument som en afhandling.

Problemet med denne type udstilling - som for alvor blev taget op med repræsentationsdebatten (Durrans 1995; Shelton 2001) - var naturligvis, at ved at indsætte genstande fra enkelte kulturer i evolutionære serier indskrev man de tilhørende samfund i forskellige tider. I den evolutionistiske udstilling blev samtidige samfund således indsat i vidt forskellige tider i bevægelsen mellem barbari og civilisation (Durrans 1995; Henare 2005; Petch 2006). Udstillingen producerede altså en tidslig forskydning mellem samtidige samfund, så de ikkeeuropæiske folk kunne ses som en del af den europæiske fortid.

Herhjemme var den eneste scene for etnografiske udstillinger indtil 1960'erne Nationalmuseet, hvor Kaj Birket-Smith residerede. Birket-Smith anerkendte ikke den implicitte civilisationsudvikling i kulturevolutionismen, men byggede i stedet sit arbejde på en blanding af tysk Kulturgeschichte og diffusionisme. Ud fra en idé om, at (erhvervs)kulturer kunne inddeles i syv hovedformer, så Birket-Smith det som museets ideelle opgave at vise disse syv former gennem relevante cases (Birket-Smith 1931; Ferdinand 1970). Mens man kan argumentere for, at der ligger en implicit evolutionistisk tænkning i hovedformernes udvikling fra „lavere jægere og samlere" til ,agerbrugere med plov" (Ferdinand 1970), var BirketSmiths idé, at hver enkelt samfundsform byggede på kulturens tilpasning til de naturlige omgivelser og dermed indeholdt sin egen logik og ikke nødvendigvis 
ville bevæge sig mod stadig mere udviklede trin. Forandring opstod derimod gennem interaktion med andre kulturer og optagelse af særlige træk fra disse.

På den måde fungerede museet også her som et laboratorium, idet det var museet, der opbevarede genstandene, de faktuelle „dokumenter“, der ville overleve vekslende teoretiske orienteringer, og det var på museet, genstandsmaterialer kunne forholdes til hinanden, så man kunne spore materielle træks - og dermed befolkningsgruppers - vandring.

Mens Birket-Smith var meget optaget af hverdagskulturen og altså ikke opfordrede til indsamling af særligt spektakulære genstande (Birket-Smith 1931), var der én form for udveksling og tilhørende genstande, som lå uden for hans interesse. Birket-Smith var interesseret $i$ at indsamle de ,rene“ kulturelle former til museet. Mens disse rene former kunne omfatte udvekslinger med andre grupper, omfattede de ikke tegn på ,industrialisme“ såsom massefremstillede varer, turistgenstande m.v. (ibid.). Dette kan ses som et forsøg på at lave den mest illustrative dokumentation af erhvervskulturernes hovedformer, men også som en del af den form for museale redningsaktioner, mellemkrigstiden og de første årtier efter 2. verdenskrig er så rig på. I disse år så man i stigende grad, hvordan industrielt forarbejdede varer vandt frem selv i det, der blev ansat som verdens fjerneste afkroge, med det resultat, at traditionelt forarbejdede produkter forsvandt. Dette afstedkom en række indsamlinger, hvis fremmeste formål var at redde resterne af den traditionelle verden, før industrialismen endeligt ville sejre og udslette verdens mangfoldighed i sit kølvand (Birket-Smith 1931; Tuxen).

Så mens Birket-Smith - og dermed den danske etnografiske museumsvirksomhed - afslog en egentlig evolutionistisk bevægelse, indeholdt den sin egen implicitte tidskategorisering. Mens de kulturelle hovedformer ikke officielt blev rangeret, lå der et tidsligt skel mellem den verden, der beboedes af lavere jægere, nomader og agerbrugere, og den industrialiserede verden. Birket-Smiths egen industrialiserede samtid havde gået gennem et syndefald, mens de andres rene former stadig kunne dokumenteres.

\section{Den etnografiske nutid}

Internationalt kan man spore det første brud med den evolutionistiske udstilling i Franz Boas' brud med American Museum of Natural History (AMNH) i New York. Museet havde været Boas' base i USA efter hans ankomst, men med tiden blev relationen mellem Boas og den amerikanske museumsverden stadig mere anstrengt. I takt med sine feltstudier blev Boas stadig mere overbevist om, at kulturer skulle forstås ud fra deres egen ramme snarere end ud fra et universalistisk evolutionistisk perspektiv. 
Dette ønskede Boas naturligvis også at integrere i sine udstillinger på AMNH. I stedet for statiske serier af genstande ønskede Boas at installere genstande i ,life scenes“, altså scenerier, der afspejlede det daglige liv, og han prøvede desuden aktivt at inddrage performances for at give tingene ekstra liv (Jackniss 1985).

Denne vinkel gik dog stik imod AMNH's direktørs intentioner. Han ønskede at holde fast $\mathrm{i}$ den overordnede evolutionistiske ramme, og til sidst måtte Boas bryde med museet. Mens dette brud på mange måder blev sigende for et mere generelt skifte $\mathrm{i}$ antropologiens historie - skiftet fra antropologien som musealt fag til universitetsfag (Sturtevant 1969; Bouquet 2001) - kom Boas' ideer på mange måder til at foregribe den form for udstillinger, man kunne se på etnografiske museer i Nordamerika og Europa mange år frem i tiden.

Med baggrund i kulturrelativisme og strukturfunktionalisme dukkede der en type udstillinger op, som vi kunne kalde „monografiske udstillinger“. Disse udstillinger gik igennem de samme kapitler, som man ville kunne finde i den etnografiske monografi, for eksempel de naturlige omgivelser, mænd og kvinders roller, social organisation, ritualer og festivaler m.v. På mange måder fulgte disse ønsker op på Boas' intentioner fra århundredeskiftet. I stedet for at præsentere de indsamlede genstande i universalistiske udviklingsserier eller kulturelle typologier indgik genstandene her i en kontekstualisering, hvorigennem de fik mening. Fra at have været dokumenter for de enkelte kulturers indplacering i en større universalistisk ramme blev genstandene nu til illustrationer underlagt de klassiske temaer for den etnografiske monografi.

Det væsentlige i forhold til spørgsmålet om tid var imidlertid, at denne kontekst ofte var så massiv, at det hele gav alt for god mening. Den monografiske beskrivelse af kulturer havde en tendens til at forklare sammenhænge så godt, at den ikke kunne forklare forandring. På mange måder søgte disse udstillinger at lægge sig op ad den naturvidenskabelige udstillings typologisering og kategorisering uden at erkende, at dens objekt - menneskelige samfund - var afgørende anderledes end naturvidenskabens (Taylor 1985). Derfor kom de kulturer, der blev præsenteret på museerne, til at fremstå som ahistoriske - uden nogen fortid og uden nogen indre dynamik til forandring (Durrans 1995). Som med erhvervskulturrammen eksisterede der et skel mellem museernes egen historiedrevne verden og de andres uforanderlige kulturtilstand.

\section{Samtiden}

I løbet af 1970'erne blev den monografiske udstilling udfordret af en ny form for hyperaktuel udstilling. Den monografiske udstilling negligerede aktuelle politiske og sociale udviklinger, der involverede de beskrevne samfund i vores egen 
verden gennem verdensmarkedet, magtpolitik m.v., og desuden blev disse udstillinger baseret i de klassiske samlinger fra århundredeskiftet, som ofte omfattede genstande, der ikke længere fandtes i deres oprindelsessteder. Derfor vandt en type udstilling frem, der dels præsenterede de beskrevne samfund som del af en større økonomisk og politisk ramme, og dels byggede på nye indsamlinger af den slags genstande, man rent faktisk kunne finde i de pågældende samfund på det pågældende tidspunkt. Vi kan kalde denne type udstilling for ,naturalistisk“ eller „,ultrarealistisk“. Som modsvar til tidligere former for udstillingers tendens til at underlægge det indsamlede materiale den herskende antropologiske teoretiske retning søgte denne type udstilling så at sige at være strengt dokumentaristisk og ateoretisk. Genstandene blev præsenteret, som man ville finde dem derude i verden, ofte med en ekstrem sans for detalje i forsøget på at opnå den korrekte præsentation af dem.

Denne type udstillinger blev meget populære hos publikum og var i en årrække kendetegnende for udstillingerne på for eksempel Tropen Museum i Amsterdam og Moesgård Museum ved Århus. Men med tiden stod det også klart, at de indebar et stort problem - tiden. Ganske vist var de udstillede genstande mere repræsentative for den aktuelle materielle kultur de steder, man beskrev på museet, men det var også klart, at det udprægede fokus på aktualitet betød, at udstillingerne meget hurtigt blev forældede. Med det ultradokumentariske blik indeholdt disse udstillinger ikke en ramme, der gav dem legitimitet ud over deres aktualitet. Og som en af fortalerne for denne form for udstillinger og indsamlinger selv erkendte, var det denne form for øjebliksbilleders lod, at de - i al deres stræben mod aktualitet - i princippet var forældede allerede på det tidspunkt, de var indsamlet (Ferdinand 1970).

Til gengæld blev de naturalistiske udstillingers behandling af verdensmarkedet og aktualiserede problemstillinger kimen til en udvikling, man har kunnet se, især i Europa, de seneste 10-15 år, hvor de etnografiske museer har fokuseret på globalisering. World Museum i Liverpool, Världskulturmuseet i Gøteborg og Haus der Kulturen der Welt i Berlin er blot et udvalg af de nye institutioner, der har skiftet det traditionelle etnografiske museums forsøg på at afdække verdenskulturer ud med en orientering mod globalisering som økonomisk og politisk proces.

Med denne udvikling har også fulgt en ny problematisering af museernes samlinger. Haus der Kulturen der Welt har taget et definitivt skridt væk fra samlinger til et fokus på inddragelsen af befolkningen og arbejde med aktuelle kunstneriske udtryk, men også på Världskulturmuseet har man produceret udstillinger - for eksempel "No name fever - HIV/AIDS in the age of globalization“ - hvor man arbejder sig væk fra en afhængighed af de tilsyneladende statiske samlin- 
ger til at udnytte den transformation og dynamik, der hele tiden omgiver museet. Man inddrager altså de sager, personer og grupper, der er med til at bevæge det samfund, museet er en del af.

Opfattelsen af samlinger som statiske og knyttet en bestemt tid bliver dog modsagt fra andre museer. Tropenmuseum i Amsterdam er således et godt eksempel på et museum, der udnytter sine historiske samlinger til blandt andet at vise, at den aktuelle hype omkring globalisering har en tendens til at overse, at globalisering har eksisteret $\mathrm{i}$ århundreder, men med forskellige udformninger og konsekvenser. På den måde bruger museet de historiske samlinger til at sætte fokus på vores egen opfattelse af vores samtid - museet behøver med andre ord ikke aktuelle genstande for at være aktuelt.

En anden retning i forsøget på at trække etnografiske museer op i deres samtid er communityudstillingerne, som især er markante i Nordamerika. Hvor de naturalistiske udstillinger især gjorde op med genstandenes repræsentativitet, gør communityudstillingerne op med museets ret til at repræsentere befolkninger, hvis efterkommere bor lige uden for museets dør. For at gøre op med dette inddrages African Americans, Greek Americans, indfødte folk m.v. i udviklingen af udstillinger, der skal præsentere dem selv eller deres mere eller mindre fjerne forfædres historie. Museet bliver således et sted, hvor disse grupper får en aktuel, politisk repræsentation. Desuden arbejder flere museer mere og mere aktivt uden for deres umiddelbare offentlige præsentation. Museer som Museum of Anthropology i Vancouver og National Museum of the American Indian i Washington DC har således oprettet centre, hvor indfødte grupper, forskere og - typisk - kunstnere arbejder sammen om at udvikle traditionelle kunstformer. Her knyttes fortid og samtid altså sammen, så museet bliver en ramme, hvor fortiden får en aktuel form.

\section{Fremtiden - fra korrespondance til effekt}

I det resterende af denne artikel argumenterer jeg for, hvorfor det kulturhistoriske museum også kan være et sted, hvor vi beskæftiger os med fremtiden. Dette skal ikke forstås på den måde, at museet bliver et sted, hvor vi skaber troværdige billeder af, hvordan fremtiden kommer til at se ud - ud over at man naturligvis kunne lege med et sådant tema $\mathrm{i}$ en særudstilling engang.

I det hele taget vil jeg gerne bryde med den idé om museet som et sted, der skaber troværdige korrespondancer til et bestemt sted eller en bestemt tid. Det særlige ved museets måde at arbejde med historien på er, at forskellige tider er til stede på samme tid. Den besynderlige indsamling og opbevaring af genstande, museerne bedriver, skaber ikke nødvendigvis et troværdigt billede af en 
anden tid eller et andet sted - i givet fald ville indsamlingsbehovet potentielt være uendeligt.

Snarere end et spejl af verden tilbyder museet et virtuelt rum, hvor verden kan træde frem for os $i$ andre former, end vi ser dem i vores daglige omgang med den. Udstillingen skaber således sin egen tid, hvor forskellige tider og steder kan være til stede på samme tid. Og det er dette virtuelle rum, der danner baggrund for museet som et sted, hvor vi kan beskæftige os med fremtiden.

\section{Objekter eller agenter}

Men før jeg kan komme til spørgsmålet om fremtiden, må vi gøre en omvej over nogle betragtninger om tingene og deres rolle på museet.

Gennem tiden har museet været anset for at være en adgang til den virkelige verden. Ved at gemme på tingene har museerne kunnet vise tilbage til verden udenfor med tingene som tegn for en betydningsmættet virkelighed. På den måde har museets genstande stort set altid været forstået som tilbageskuende. De har været udtryk for en forudgående mental idé, de har været løsningen på et forudgående problem, eller de har været identitetsmarkører, der har sikret personer og grupper en relation til historien, traditioner m.v.

Permanensen er naturligvis en væsentlig del af den måde, materielle genstande indgår som del af det sociale liv på. Annette Weiner (1992) har for eksempel vist, hvordan særlige ikke-forgængelige ting kan få status som ,inalienables" - de ting, der for alt i verden skal holdes uden for cirkulation for at sikre et samfund en relation til fortiden og en bro til fremtiden.

Men permanensen er ikke alt. Det store problem ved antagelsen om, at ting først og fremmest er tilbageskuende mod en allerede eksisterende social eller mental virkelighed, er, at det får os til at overse, at tingene principielt har et uendeligt antal måder, de kan indgå i sociale relationer på. Ting indgår ikke i vores verden som uomtvistelige tegn eller dokumenter, men deltager konstant $i$ at skabe nye verdener (Gell 1998; Strathern 1999; Henare et al. 2007). De indgår i vores forsøg på at åbne verden for nye handlemuligheder. Det rigt udsmykkede Asmatskjold viser ikke tilbage til en meningsgivende kontekst, der kræver passende fortolkning, men søger derimod en umiddelbar effekt - nemlig at nedbryde modstanderen mentalt inden den kamp, der venter forude (Gell 1992).

Inger Sjørslev har også tidligere i nærværende tidsskrift vist, hvordan museets drift mod at skabe permanens kan gå direkte imod tingenes orientering mod effekt (Sjørslev 2001, 2008). I dette tilfælde var det en samling af brasilianske candomblestatuer af gips, der var blevet våde under den lange transport fra Brasilien, som Nationalmuseets konservatorer kastede sig over. Men som Sjørslev poin- 
terede, var ideen med statuerne som del af candombleritualet netop, at de ved at blive nedbrudt kan udløse deres magiske effekter. Museets stærke fokus på historie, identitet og kontinuitet kan altså indimellem gå direkte imod tingenes evne til at skabe effekter.

Snarere end at pege bagud mod forudgående traditioner, begreber og mentale forestillinger kan vi altså argumentere for, at tingene går forud for handlinger og forud for koncepter og dermed ikke reproducerer etablerede verdener, men optræder i et uvist og ufærdigt rum.

Men hvis verden er bygget på effekter snarere end reproduktioner af etablerede verdener, må det også være museets rolle at skabe sådanne effekter. På museet har vi i mange år set det som vores største opgave at sikre vederhæftig viden gennem etablering af den korrekte korrespondance mellem tingene og verden. Hvilken slags genstand er der tale om, hvilke materialer er den lavet af, hvem har brugt den til hvad, er der tale om en autentisk udgave eller en souvenir, hvordan har vi fået den? Alle disse spørgsmål har legitimeret tusindvis af arbejdstimer på museerne. Og med god grund. I en verden, hvor viden flyder, er der god ræson i at fastholde en institution, der gør sit yderste for at levere oplysninger, der bygger på velfunderet viden.

Med udgangspunkt i effekt kan vi imidlertid argumentere for, at det ikke er museets rolle at skabe noget, der ligner verden udenfor på nogen repræsentativ facon - altså gennem naturalistiske gengivelser eller ved kun at udstille genstande sammen, der beviseligt kommer fra samme sted eller tid. Derimod må vi stræbe efter at anskueliggøre og virkeliggøre effekter.

Men effekter er altid knyttet til teorier om verdens sammenhæng. Der er for eksempel helt andre muligheder for effekter i et samfund, hvor magi eksisterer, end $i$ et, hvor man afviser magi. På museet vil det betyde, at for at lave en udstilling om magi må vi installere magi. Vi må lave rum, der gør magien nærværende og til en mulighed for et hjemligt publikum - vi må skabe rum, der så at sige tager magten fra publikum.

Et eksempel på dette kunne være udstillingen „Drømmens søster“, der for nylig blev vist på Nationalmuseet. ${ }^{3}$ Udstillingen handlede om myter blandt indfødte folk ved Orinoccofloden og var bygget op, så man gik rundt $i$ en stiliseret regnskov. På særlige steder i den labyrintiske opbygning blev man ramt af en stemme, der fortalte uddrag fra myterne. Hele denne opbygning fik myten til at træde langt stærkere frem som effekt snarere end som et narrativ, der kun har en tekstlig form.

Et andet eksempel kunne være Nordvestkystudstillingen på American Museum of Natural History. Denne udstilling er en viderebygning af Boas' gamle udstillinger, og den er tydeligvis ikke blevet opdateret i mange år. Men hvor man på 
mange andre museer i Nordamerika arbejder med rekonstruktioner af beboelser, ${ }^{4}$ arbejder denne udstilling med det konkrete museumsrum, der er udstillet i. Man træder ind i et stort, meget højloftet rum, hvor den øverste del af væggene er udsmykket med malerier af forskellige nordamerikanske indfødte grupper. Op gennem rummets midte er der en bred gang, og symmetrisk på hver side af denne gang er rummet opdelt i fire afsnit. Ved overgangen mellem hvert afsnit har man placeret en enorm (5-7 meter) udsmykket housepost. Denne opbygning giver disse houseposts al den ærefrygtindgydende autoritet, man kan forestille sig, de skal have haft, uden at de indgår i en efterligning af den verden, de er taget fra. Frem for at stå som flade efterligninger af verden derude trækker denne installation altså på den autoritet, museet har.

Men for at lade museet gribe ind i fremtiden må vi gå videre end til at installere effekter. Vi må arbejde med udstillingsdesign, der indtænker sit publikum både inden for og uden for museets mure.

\section{Tilbage til laboratoriet}

På mange måder er de seneste årtiers nye fokus på agens og effekt i lige så høj grad en tilbagevenden til et blik, hvor ting bliver fritaget for at være emblemer, instrumenter eller symboler for i stedet at optræde på lige fod med andre agenter. I museumssammenhæng ser en mulig konsekvens af de nye materialitetsteorier da også ud til at være, at vi må vende tilbage til museets udgangspunkt - nemlig museet som laboratorium. I det, der er blevet kaldt antropologiens ,,museumsperiode“ (Sturtevant 1969; Ames 1992) fra slutningen af 1800-tallet til 1920'erne, ${ }^{5}$ fungerede museet grundlæggende som et laboratorium. I den britiske tradition blev det indsamlede materiale brugt til at kortlægge den kulturelle evolutions stadier, mens man i den tyske, diffusionistiske tradition kortlagde de kulturelle træks vandring og dermed relationerne mellem kulturelle grupper.

Fælles for de to tilgange er, at museet regnes for at kunne udsige noget mere, end vi kan erkende ved blot at se os omkring i verden. Ude i verden kan vi se folk bruge redskaber, tøj m.v. og prøve at skabe en sammenhæng mellem konkrete personers handlinger, ytringer og den materielle verden, de omgiver sig med. Men på museet kan vi se bag om denne umiddelbarhed og skabe et helt andet billede af verden, som er funderet på lange evolutionistiske bevægelser eller historiske udvekslinger og tilegnelser. I denne tradition er man altså bevidst om, at den verden, vi beskæftiger os med på museet, ikke svarer til den verden, vi oplever i vores daglige, menneskelige omgang med verden.

Selv om evolutionismen og diffusionismen måske ikke er så relevante i den aktuelle antropologi, er der i de senere år sket en udvikling, der gør laboratorie- 
betegnelsen relevant igen. Overordnet dukker betegnelsen op i to forskellige sammenhænge: i forhold til museet som et socialt laboratorium og i forhold til genskabelsen af museet som et centralt element i den antropologiske forskning. Selv om de to dele er nært knyttet, vil jeg for overblikkets skyld behandle dem hver for sig.

\section{At samle og forsamle - museet som ting}

Museets mest åbenbare karakteristika er vel nok den massive indsamling af ting, som indimellem kan få institutionen til at fremstå komplet irrationel. Museerne indsamler og bevarer - og udstiller typisk mellem 3 og 5 procent af alle de ting, de har indsamlet. Og selv om de sidst 95-97 procent af genstandene ikke ligger stille hen - der bliver forsket, anvendt til særudstillinger, lånt ud m.v. - vil de fleste med erfaring fra museumsarbejde kunne nikke genkendende til, at end ikke de ansatte, der burde kende bedst til samlingerne, ved, hvilke ting samlingerne rummer, hvor de ligger, og hvad formålet med at indsamle dem har været.

Men det er ikke kun ting, der bliver samlet på museet. Meget tidligt var man bevidst om de muligheder, der lå i at samle befolkningen i museet. De tidligste moderne udstillinger i England, der byggede på erfaringerne fra Verdensudstillingen $\mathrm{i}$ Crystal Palace i 1851, kunne således ses som bevidste bestræbelser på at danne arbejderklassen (Bennet 2005). Mens museet tidligere havde været eksklusivt for borgerskabet, gjorde verdensudstillingens store succes det klart, at museet havde et enormt potentiale til at danne arbejderklassen, dels gennem indholdet af det udstillede, men nok så meget ved at bruge museet som et sted, hvor arbejderklassen kunne se, hvordan borgerskabet opførte sig, og dermed lære, hvordan man burde opføre sig som dannet samfundsborger.

Senere hen i det etnografiske museums historie har museet virket som en platform, hvor man har kunnet opleve konkrete, førstehåndsmøder med de befolkninger, der er blevet udstillet på museet, ligesom museet har været brugt til at give forskellige minoritetsgrupper en konkret repræsentation.

Alt dette peger hen imod en erkendelse af, at museet ud over at indsamle har en væsentlig funktion i sin evne til at forsamle. Denne pointe tog Bruno Latour og hans medkurator Peter Weibel alvorligt i udstilling Making Things Public på ZKM i Karlsruhe i 2005 (Latour 2005). Udgangspunkt for denne udstilling var den dobbelte betydning af ordet „ting“. For det første udfordrer ordet „ting“ vores forståelse af museets fokus på objekter. Latour afviser den objektivistiske tilgang til ting, forstået som materielle enheder, der fastholder en særlig betydning og udstrækning gennem deres tilværelse. I stedet argumenterer Latour for, at en „ting“" er under konstant forandring, i og med at den hele tiden knytter nye 
interesser, nye forsamlinger sammen. En ting er ikke noget i sig selv, men kun som del af et kollektiv, og da de kollektiver, tingene optræder i, er under konstant forandring, forandres ,tingen“" også.

Dette fører han videre til den anden betydning af ordet „ting“, nemlig i den oldnordiske betydning som en forsamling, hvor vi samles for at diskutere fælles problemstillinger. I modsætning til vore dages politiske liv bestod disse ting ikke af repræsentative forsamlinger i form af parlamentariske systemer, men derimod af forsamlinger af folk, der delte et problem og ønskede at diskutere dette. Dette er ifølge Latour problemet ved det moderne parlamentariske system - at det antager, at særligt udvalgte kan tage stilling til alt. Dermed bliver det politiske til et spil i sig selv snarere end et sted, hvor vi diskuterer vores konkrete „objects of concern".

Det er her, museet kommer ind. Ved at danne en konkret ramme for vores møde, en konkret erfaring, som vi deler, udgør museet et potentiale for at skabe sådanne ting, forstået som skiftende forsamlinger af personer, der deler et ,object of concern“. Museet kan være med til at understrege, at ethvert ting således har sin egen arkitektur. Alt kan ikke diskuteres på samme måde, hvilket betyder, at vi ikke kan forsamles på samme måde for at løse de mange forskellige „objects of concern", der knytter os sammen. Gennem at sætte en særlig fysisk ramme, der kan ændres, kan museets således ikke blot arbejde med at udvikle nye udstillingsdesign, men også nye forsamlingsdesign - nye rammer for det politiske liv, hvorigennem vi kan skabe nye fremtidsscenarier.

Man kan forestille sig mange forskellige udmøntninger af sådanne fremtidsscenarier. En model er de nordamerikanske kulturcentre, jeg nævnte tidligere. Her bruger man museet som ramme for at lade forskere, indfødte folk, kunstnere og andre relevante grupper mødes for at diskutere og udvikle aktuelle processer, der involverer de indfødte folk.

En anden mulighed er at lade udstillinger træde frem i forskellige former - den konkrete udstilling, hjemmesider, happenings m.v. - så publikum ikke blot møder udstillingen som et færdigt rum, men konfronteres med dens tema $i$ andre former i andre rum. I forbindelse med udstillingen „Villa Sovietica“ på Musée d'ethnographie de Genève i 2009-2010, som handlede om hverdagsliv i Sovjetunionen, inviterede man publikum til at være med til aktiviteter på museet, som de på forhånd ikke kendte indholdet af. Én dag plantede man blomsterløg med publikum i den park, der omgiver museet. Efter at have hygget sig med havearbejde tog man publikummerne med op på museets førstesal, hvorfra de kunne se, hvad de havde plantet - et portræt af Lenin. En anden dag udstyrede man de fremmødte publikummere med 80 af den slags store plastiktasker, mange østeuropæere rejser med. Deltagerne blev bedt om at transportere taskerne med bus og båd ned til byens centrale plads. 
Ideen med disse events var naturligvis at skabe alternative billeder af, hvad det vil sige at være østeuropæer, men nok så meget at engagere publikum i en diskussion om forholdet mellem øst og vest fra en ny indgangsvinkel.

Ved at udnytte, at museet er et konkret rum, hvor vi mødes fysisk omkring en oplevelse eller aktivitet, kan vi gøre museet til et socialt laboratorium, hvor vi eksperimenterer med måder at være sammen på og med at skabe nye visioner for, hvordan vi forholder os til vores fælles „objects of concern“.

\section{Form og forskning}

Inddragelse af publikum på museets mange platforme (udstilling, events, foredrag, hjemmeside m.v.) er efterhånden en fast del af museernes virke. Men en stort set overset effekt af denne inddragelse er, at den kan få betydning for forskningen.

I de senere år har der været stor fokus på museernes formidling. Formidling på et museum tager oftest udgangspunkt i en faglig indsigt, som skal præsenteres for et publikum, så den står klart og tydeligt frem. Der eksisterer altså en idé, som skal have en passende form, så den kan begribes af et bredt publikum.

Jeg vil ikke afvise denne fremgangsmåde, der som oftest heller ikke er så ligetil endda. Men hvis museet skal beskæftige sig med fremtid, må der andre ideer i spil.

Bateson har engang argumenteret for, at den eneste kilde til nye mønstre er støj (Bateson 2000:416). Mens det ultimative mønster er sproget, skal støj forstås som det, der ligger ud over mønstrene, det, der ikke umiddelbart kan dechifreres eller gøres til genstand for fortolkning. Hvis vi skal oversætte dette til museet, vil det sige, at vi netop ikke altid skal formidle, men indimellem skabe noget, der åbner op for muligheden for at se nye mønstre tegne sig. Vi skal tillade, at tingene indgår i nye sammenhænge, for at undersøge, hvilke nye ideer der kan dukke op.

Det er her ideen om forskningens laboratorium dukker op. Museet har nemlig en fantastisk mulighed for at fremstå som et eksperimentarium, hvor forskningen udfordrer og lader sig udfordre af publikum - en slags tredje felt, anderledes end både felten derude og den akademiske felt herhjemme.

Jeg kan ikke pege på nogen museer, der har taget denne opgave på sig endnu, så jeg må i skrivende stund være lidt uklar, når jeg prøver at beskrive, hvad denne tredje felt - museet som eksperimentarium - kunne blive til. Men udgangspunktet for den ligger i museet som et sted, hvor vi arbejder med former og koncepter.

Der er i de senere år givet flere eksempler i antropologien på, hvordan form kan bære koncepter, der ikke eksisterer uden formens tilstedeværelse (se for eksempel Henare et al. 2007). Det centrale i disse betragtninger er naturligvis, at 
formen kan have sin egen ret og ikke blot skal bedømmes på sin evne til at vise tilbage til en forudgående idé - og at ideer (i hvert fald i visse tilfælde) kræver en form for at kunne eksistere. Den interessante udfordring for museet er, om man kan skabe former, der går forud for ideer - altså former, der ikke gør etableret viden mere forståelig, men derimod kan åbne op for nye ideer. Dette ville kunne give museet en helt ny central rolle for forskningen.

For det første ville det kunne åbne op for museet som en platform, som forskningen kunne udnytte til at arbejde med andre måder at udveksle ideer på end gennem tekst. Museets genstande, rum og diverse udstillingsfaciliteter (lys, lyd, digitale installationer m.v.) giver mulighed for, at man kunne udveksle gennem at skabe former og atmosfærer, der kunne udvikle nye ideer.

For det andet giver adgangen til publikum en mulighed for at udvikle teori gennem praksis. Taylor (1985) har argumenteret for, at socialvidenskaberne er så knyttet til den verden, de undersøger, at de kun lader sig validere ved at blive udfoldet i praksis. Museet tilbyder her en gylden mulighed for at lade teorien udfordre af publikum: Hvorvidt virker de problemstillinger, vi præsenterer, til at være vedkommende for publikum, og hvorvidt åbner vores præsentationer op for, at publikum tænker videre og udfordrer vores ideer? Der er et stort potentiale $\mathrm{i}$ at udvikle museumsorienterede metoder, der på denne måde ikke blot inddrager publikum, men også søger at udnytte publikums reaktioner og refleksioner til at udvikle nye forskningsspørgsmål.

Hvis vi accepterer dette, vil det imidlertid kræve en helt ny tilgang til udstillinger. Fra at være et sted, hvor videnskaben formidler sin viden og derefter trækker sig tilbage, vil en videre udforskning af tingenes potentialer afkræve, at udstillingen bliver en aktiv del af forskningen. Udstillingen er således ikke længere et sted, hvor vi udstiller sikker viden, men derimod et sted, vi må give os hen $\mathrm{i}$ - nok med autoritet, men uden sikker viden om, hvor vi ender.

Det, jeg har plæderet for i denne artikel, skal ikke forstås som et brud med alt, hvad der er gået forud på museerne, eller et programmatisk råb om et paradigmeskifte. Jeg har blot ønsket at understrege, at museet har et potentiale for at beskæftige sig ikke blot med fortid og nutid, men også med fremtiden. For at gøre dette må museerne imidlertid bryde med idealet om at skabe troværdige repræsentationer af det allerede skete. I stedet må vi se udstillingen i sig selv som en måde at skabe nye effekter ud af genstandene, der tillader os at kaste os ud i nye forestillinger om, hvordan verden kan se ud. For at gøre dette bliver vi nødt til at lave lidt støj - vi må gå ud over vores egen vished og bruge museet til at lege med vores forestillinger for at lade nye mønstre tegne sig.

Søgeord: Museer, materialitet, effekt, fremtid, udstillinger, demokratiske rum 


\section{Noter}

1. Denne artikel bygger på afsnit fra ph.d-afhandlingen „Inside the Museum Machine“. Ph.d.-projektet blev udført i samarbejde med Moesgård Museum og Institut for Antropologi, Arkæologi og Lingvistik ved Aarhus Universitet og modtog økonomisk støtte fra Erhvervs-ph.d.-ordningen og Knud Højgaards Fond. Jeg vil gerne takke en anonym bedømmer og professor Rane Willerslev for kommentarer og ideer.

2. Jeg skal gøre klart, at den inddeling i udstillingstyper, jeg trækker frem igennem artiklen, naturligvis dækker over, at de enkelte typer udstillinger eksisterer side om side. De evolutionistiske udstillinger eksisterede i Storbritannien langt op i 1960'erne (Shelton2001), og den monografiske udstilling er stadig udbredt i dag (interessant nok er dette en stil, der blandt andet er til stede på „,community museums“ I USA, hvor indfødte grupper præsenterer sig selv), og den naturalistiske udstilling er også vidt udbredt i dag. Artiklen præsenterer således ikke en evolution i udstillingstyper, men fremhæver forskellige måder, hvorpå tiden implicit er blevet problematiseret i udstillinger.

3. Udstillingen var et lån fra Världskulturmuseet i Gøteborg, hvor den indgik som en af åbningsudstillingerne i 2004.

4. Det ekstreme tilfælde er her The MashantucketPequot Museum, hvor man har rekonstrueret en hel landsby med dagligdags scenerier med fantastisk livagtige dukker. Dette skaber naturligvis sin helt egen effekt, hvilket imidlertid også har krævet en solid økonomi, der er blevet hentet fra det nærliggende casino, som pequoterne ejer.

5. Ret beset falder museumsperioden på forskellige tidspunkter. I USA er periodens ophør nært knyttet til Boas' opgør med American Museum of Natural History, mens antropologien i Danmark stadig var nært knyttet til museet op til 1950'erne, hvor Kaj Birket-Smith rådede på Etnografisk Samling på Nationalmuseet.

\section{Litteratur}

Ames, Michael

1992 Cannibal Tours and Glass Boxes: The Anthropology of Museums. Vancouver: University of British Columbia Press.

Bateson, Gregory

2000 [1972] Steps to an Ecology of Mind. Chicago \& London: The University of Chicago Press.

Bennet, Tony

2005 [1996] The Exhibitionary Complex. I: R. Greenberg, B.W. Ferguson \& S. Nairne (eds.): Thinking About Exhibitions. London: Routledge.

Birket-Smith, Kaj

1931 Om Indsamling af etnografiske Sager. En Maade hvorpå danske i Udlandet kan gøre det gamle Land en Tjeneste. Særtryk af Danmarksposten, vol. 2, ikke pagineret.

Bouquet, Mary

2001 Streetwise in Museumland. Folk, Journal of the Danish Ethnographic Society 43: 77-102. 
Durrans, Brian

1995 [1988] The Future of the Other: Changing Cultures on Display. I: R. Lumley (ed.): The Museum Time-Machine: Putting Cultures on Display. London \& New York: Routledge.

Faber, Paul (ed.)

2003 Group Portrait South Africa: Nine Family Histories. Kwela: Johannesburg.

Ferdinand, Klaus

1970 Etnografien på Moesgårdmuseet. Samlingen og noget om at indsamle etnografika. KUML 19.

Gell, Alfred

1998 Art and Agency: An Anthropological Theory. Oxford: Clarendon Press.

1992 The Technology of Enchantment and the Enchantment of Technology. I: J. Coote \& A. Shelton (eds.): Anthropology, Art and Aesthetics. Oxford: Clarendon Press.

Henare, Amiria J.M.

2005 Museums, Anthropology and Imperial Exchange. New York: Cambridge University Press.

Jacknis, Ira

1985 Franz Boas and Exhibits: On the Limitations of the Museum Method of Anthropology. I: G.W. Stocking (ed.): Objects and Others: Essays on Museums and Material Culture. Madison: University of Wisconsin Press.

Latour, Bruno

2005 From Realpolitik to Dingpolitik, or How to Make Things Public. I: B. Latour \& P. Weibel (eds.): Making Things Public: Atmospheres of Democracy. Cambridge, MA: MIT Press, \& Karlsruhe: ZKM/Center for Art and Media in Karlsruhe.

1999 Pandora's Hope: Essays on the Reality of Science Studies. Cambridge, MA, \& London: Harvard University Press.

Petch, Alison

2006 Chance and Certitude: Pitt Rivers and his First Collection. Journal of the History of Collecting 18:249-56.

Schüssler, Alexandra (red.)

2009 Villa Sovietica. Soviet Objects: Import-Export. Udstillingskatalog. Gollion: Infolio éditions \& Genève: Musée d'ethnographie de Genève.

Shelton, Anthony

2001 Museums in an Age of Cultural Hybridity. Folk, Journal of the Danish Ethnographic Society 43:221-50.

Sjørslev, Inger

2008 Fra kultur til kurator: Kunst og kontekst i udstillingen af etnografika. I: M.R.

Melchior \& C. Mordhorst (red.): Udstillingens idé og form. København:

Københavns Universitet.

2001 Den opløste samling og den magiske materie. Tidsskriftet Antropologi 43-44: 3544.

Sturtevant, William

1969 Does Anthropology Need Museums? Proceedings of the Biological Society of Washington 82:619-50. 
Taylor, Charles

1985 Social Theory as Practice. I: C.Taylor: Philosophy and the Human Sciences.

Cambridge: Cambridge University Press.

Tuxen, Søren Ludvig

n.d. Privat brev. De Etnografiske Samlinger på Moesgård Museum.

Weiner, Annette

1992 Inalienable Possessions: The Paradox of Keeping-While-Giving. Berkeley, Los Angeles \& London: University of California Press. 